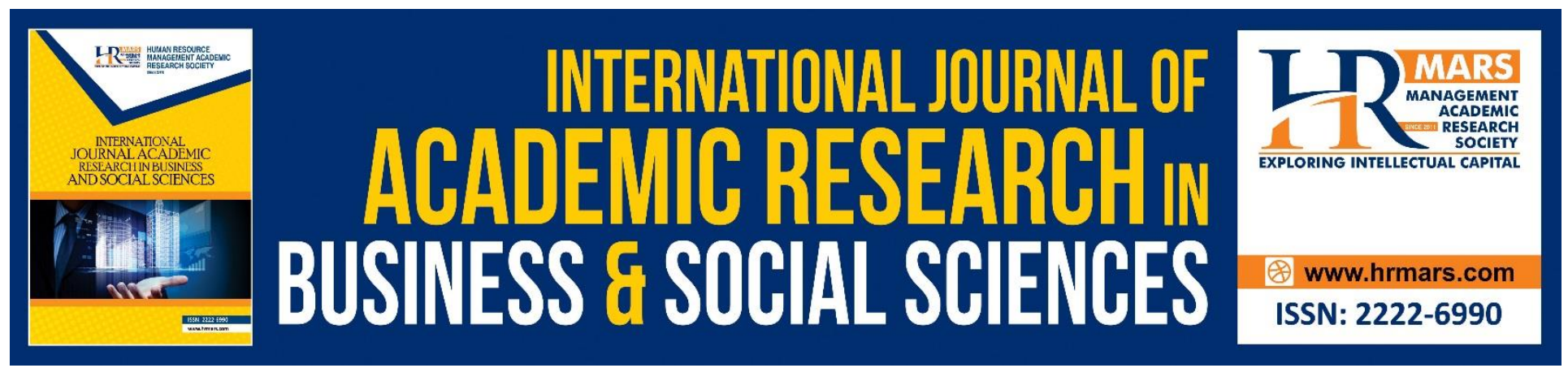

\title{
Understanding the Elements of Developing a Harmonious Society in the Literary Masterpiece of Kalilah wa Dimnah
}

Pabiyah Toklubok, Kamariah Kamarudin, Zaitul Azma Zainon Hamzah, Raihan Marzuki

To Link this Article: http://dx.doi.org/10.6007/IJARBSS/v10-i11/7747

DOI:10.6007/IJARBSS/v10-i11/7747

Received: 01 September 2020, Revised: 26 September 2020, Accepted: 11 October 2020

Published Online: 05 November 2020

In-Text Citation: (Maon, Hassan, \& Jamaluddin, 2020)

To Cite this Article: Toklubok, P., Kamarudin, K., Hamzah, Z. A. Z., \& Marzuki, R. (2020). Understanding the Elements of Developing a Harmonious Society in the Literary Masterpiece of Kalilah wa Dimnah. International Journal of Academic Research in Business and Social Sciences. 10(11), 1-15.

Copyright: (C) 2020 The Author(s)

Published by Human Resource Management Academic Research Society (www.hrmars.com)

This article is published under the Creative Commons Attribution (CC BY 4.0) license. Anyone may reproduce, distribute, translate and create derivative works of this article (for both commercial and non-commercial purposes), subject to full attribution to the original publication and authors. The full terms of this license may be seen

at: http://creativecommons.org/licences/by/4.0/legalcode

Vol. 10, No. 11, 2020, Pg. 1 - 15

Full Terms \& Conditions of access and use can be found at http://hrmars.com/index.php/pages/detail/publication-ethics 


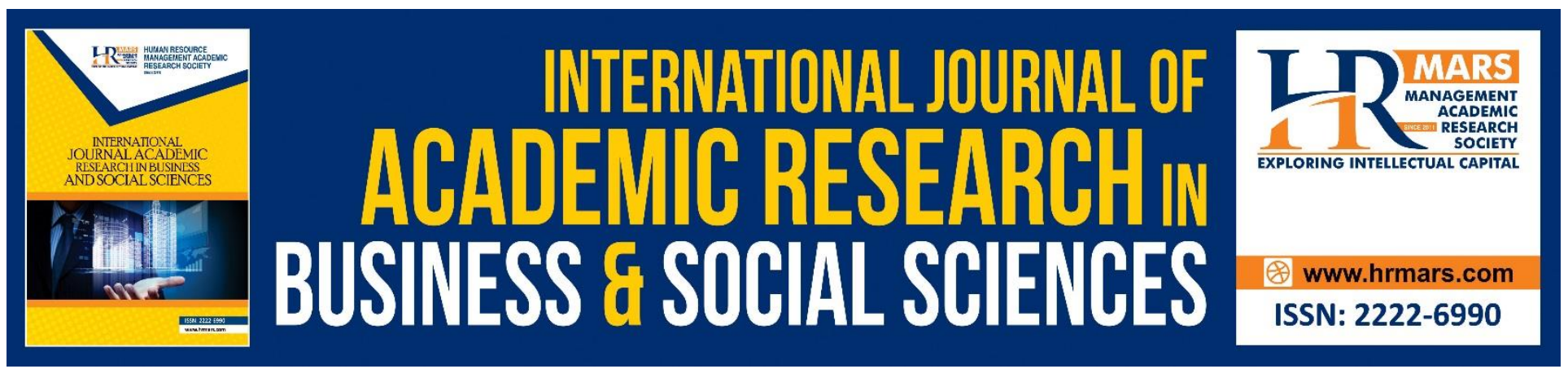

\title{
Understanding the Elements of Developing a Harmonious Society in the Literary Masterpiece of Kalilah wa Dimnah
}

\section{Pabiyah Toklubok ${ }^{1}$, Kamariah Kamarudin², Zaitul Azma Zainon Hamzah $^{2}$, Raihan Marzuki ${ }^{3}$}

${ }^{1}$ Department of Foreign Languages, Faculty of Modern Languages and Communication, Universiti Putra Malaysia, ${ }^{2}$ Department of the Malay Language, Faculty of Modern Languages and Communication, Universiti Putra Malaysia, ${ }^{3}$ Institute of Diplomacy and Foreign Relations (IDFR),

Ministry of Foreign Affairs, Malaysia

Email: pabiyah@upm.edu.my, http://profile.upm.edu.my/pabiyah

\begin{abstract}
The Abbasid caliphate was the longest reigning caliphate in the history of Islamic civilization. The reign of the Abbasid caliphate began in $132 \mathrm{H}$ but collapsed in $656 \mathrm{H}$. The turbulent situation that has plagued the Abbasids has prompted some authors to produce literary works in various genres, both prose and poetry. Among them was Abdullah Ibn al-Muqaffa' who shifted his focus towards translating the Kalilah Wa Dimnah (KWD) book from Persian to Arabic. This effort is aimed at educating Abbasi leaders and communities by channeling moral values through the KWD book. This work is considered a masterpiece because it contains significant content based on moral values and guidance conveyed implicitly through the voices of animal characters. A total of five stories in the book of KWD was analyzed based on the moral values highlighted by Imam al-Ghazali. The eight aspects of these moral values are identified and classified based on four essential elements namely al-Hikmah (wisdom), al-Syaja'ah (courage), al-'Iffah (purity) and al-'Adlu (justice). The results of this study indicated that the author aligned al-Hikmah elements with the wisdom of setting strategies and the ability to trigger accurate thoughts. Meanwhile, Al-Syaja'ah elements were in line with the values of bravery in overpowering the enemy as well as inferiority. The al-'Iffah elements were in line with mutual aid values as opposed to maliciousness. The al-'Adlu element was next in line with unconditional love and generosity values. It can be concluded that these four elements contributed to translating the values contained in the KWD and in turn served as a guide to the general readership of leaders in exercising their responsibility to their communities in the pursuit of developing a harmonious society.
\end{abstract}

Keywords: Kalilah Wa Dimnah, Abdullah Ibn Al-Muqaffa', Moral Values, Al-Ghazali, Harmonious Society 
INTERNATIONAL JOURNAL OF ACADEMIC RESEARCH IN BUSINESS AND SOCIAL SCIENCES Vol. 10, No. 11, 2020, E-ISSN: 2222-6990 @ 2020 HRMARS

\section{Introduction}

The Abbasid caliphate was founded after the fall of the Umayyad empire in $132 \mathrm{H}$, which in turn reigned for 524 years. However, due to the tyranny of some of its caliphs such as Abu Ja'far al-Mansur, the Abbasid caliphate eventually fell into the hands of the Tatars (Al-Fakhuri, 1991). During this period, severe mismanagement and violence led to distress and poverty among their societies (AlThubaity, 2006). This situation has sparked dissatisfaction among the Arabs which in turn resulted in the downfall of the Abbasid caliphate. Various efforts were made to restore a moral awareness among the rulers. These included efforts in the aurthorship and production of literary works. Efforts to educate the ruling body in restoring the peace and harmony of their community were helmed by literary authors through their work in prose and poetry. This is because literature was not only intended to entertain or merely exist as a source of entainment to readers, but also to play a pivotal role in channeling ideas and views on issues that plagued Islamic society during those periods. Upon realizing the potential of literature, authors such as Abdullah Ibn al-Muqaffa' were able to offer their views, criticisms and advice through literary masterpieces like the Kalilah wa Dimnah.

Initially, during its conception, the Kalilah Wa Dimnah (hereinafter referred to as the KWD) was written to be presented to Indian kings who were notorious for cruelty; hence prompting Abdullah Ibn Al-Muqaffa' to translate the book to be targeted specifically at Caliph Abu Jaafar alMansur, the Abbasid Caliph at that time (Al-Fakhuri, 1991). Although this purpose was not explicitly stated, it can be thoroughly observed through the expressions in the KWD where the author is quoted as saying: (Hasan, 1984: 24)

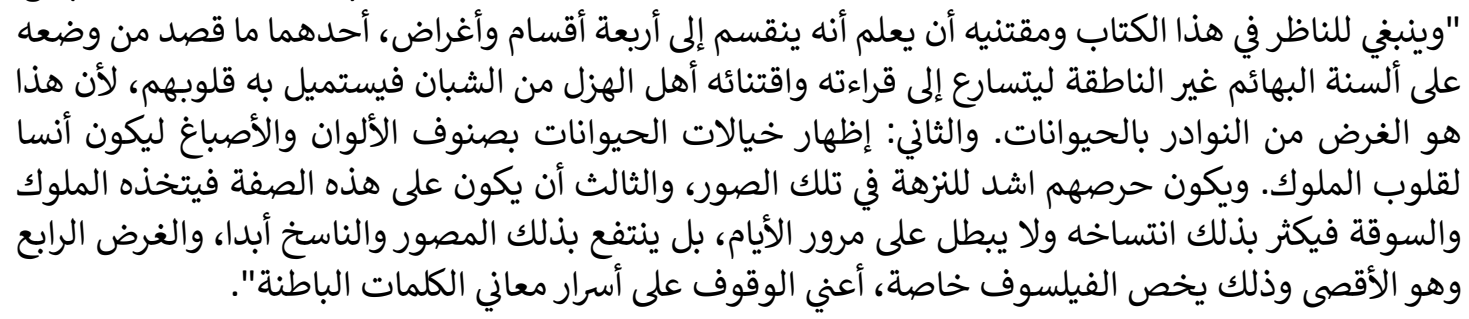

"For he who has read this book and owns it should know that it is divided into four parts and purposes, one of them is intentionally written in the language of animal in order to hasten the reading and attract the ownership of the young people who are interested in the book, for this purpose, the prose contains animal-based anecdotes. Secondly, it is to portray the imagination of animals in various forms to entertain the kings, hence they may be more immersed by the imagery. The third is to make the reader learn from the tales, be it kings or commoners, so that it may be copied ubiquitously, and as time passes, even painters and copyists shall continue to benefit, and the fourth purpose, most importantly, is especially for philosophers. I mean, to see the secrets hidden within the meanings of these words."

Hence, the reason that prompted the author to translate the Kalilah Wa Dimnah book was so that it could be used as an educational medium for the Abbasid leaders and the community, emphasizing on moral values. For the learned scholars of that period, the current situation of the kingdom could be related with the character scenarios presented by Abdullah Ibn al-Muqaffa' via the KWD translation. It can be deduced that by reading this literary work, the moral values conveyed through 
INTERNATIONAL JOURNAL OF ACADEMIC RESEARCH IN BUSINESS AND SOCIAL SCIENCES Vol. 10, No. 11, 2020, E-ISSN: 2222-6990 @ 2020 HRMARS

the message embedded in its stories indirectly affected the readers, thus enabling them to learn lessons to serve as a guide in creating a harmonious society.

According to Omar (2015), the construction and creation of a literary work should have an abundance of aesthetics and beauty in addition to containing a significant amount of moral elements in order to serve a good purpose to the readership. The moral values analyzed in the context of this study comprises of positive values that each individual should posses in order to avoid any deviation from the social norms of society. These include values such as sincerity, loyalty, honesty, patience, trust, gratitude, trust in God's plan, kindness and responsibility. In fact, literary works are closely related to daily life because each work is usually a reflection of the author's experience, observations, studies and hopes. Therefore, the objectives of this study are as follows:

- To identify the moral values of the Kalilah wa Dimnah

- To exemine the identified moral values of the KWD based on the four fundamental elements founded by Imam al-Ghazali

\section{Literature Review}

The turmoil that ensued before the fall of the Abbasid caliphate inspired Abdullah Ibn al-Muqaffa' to shift his focus towards the Kalilah Wa Dimnah's translation from Persian to Arabic (Al-Fakhuri, 1991). Aidah Iwadh's study indicated that there was a relationship between the current situation of the time and the values that the author wished to convey in producing their work (Iwadh, 1982). This finding is in line with Bertens' statement likening the translation of the book of Kalilah wa Dimnah by Abdullah Ibn al-Muqaffa' as a form of social criticism, aimed at criticizing the Abbasid rulers as well as depicting the realities of the time (Bertens, 2002). Among the key issues raised by Abdullah Ibn alMuqaffa' in the KWD are; government issues and the government's duty towards the people, the qualities that a government should possess such as justice, the welfare of the people, and finally the service of the people. In addition, virtues of friendship such as sincerity, love, truthfulness of words and deeds as well as respect towards guests were emphasized in this literary work (Athar Ibn alMuqafa ', 1978).

\section{Kalilah wa Dimah the Arabic Masterpiece}

The Kalilah Wa Dimnah is a well-known classic literary work by Abdullah Ibn al-Muqaffa' (106H$142 \mathrm{H}$ ); an author of Persian origin and a pioneer of Arabic prose from the Abbasid times (Al-Rafie, 1968). His translation work has had a significant impact on the historical development of Islamic literature. Since its emergence, it has evolved a style of prose writing that uses dialogue and animal life as its background with the aim of improving human morals and behavior. The Kalilah Wa Dinmah or 'Panchatantra' has been popular for over two thousand years and is still a popular attraction for readers throughout the Arab world (Lunde, 1972). This work of Ibn al-Muqaffa's translation uses free, non-binding translations and he tries to adapt some new sections of his translation to suit the teachings of Islam, in line with the tastes of local writers of that time (Khalid, 1989).

The Kalilah wa Dimnah is known as the 'Panchatantra' in Hindu society (Al-Subayel, 2007) or 'Five Discourses' which means 'Five Animal Stories'. It is also known as Aesop's Fables in the Greek literature (Hancock, 2004). Initially, this work was originally a Hindu literary work and it was meticulously compiled in Sanskrit by a philosopher named Baidaba, in order to fulfill the request of an Indian king known as the Emperor Dabsyalim (Khalid, 1989: Al-Subayel, 2007). In its earliest form, the book was translated from Sanskrit into Persian by al-Barzawy, a physician of the King Anusyirwan 
INTERNATIONAL JOURNAL OF ACADEMIC RESEARCH IN BUSINESS AND SOCIAL SCIENCES Vol. 10, No. 11, 2020, E-ISSN: 2222-6990 @ 2020 HRMARS

(Al-Muqaffa', n.d.), henceforth entitled Kalile va Demne (Sidik, 2012). Abdullah Ibn al-Muqaffa' was the individual responsible for translating the book from Persian into Arabic, therefore introducing it by the name Kalilah Wa Dimnah. The title is based on the name of two wolves who are the main characters in the first story of the compilation (Lunde, 1972). The main characters in the Kalilah Wa Dimnah are a lion as King of the Wild, two male wolf siblings named Kalilah and Dimnah, a bull named Shatrabah and several other animals as companions and assistants of the King of the Wild (Musa, Otunuyi, \& Ahmed, 2012). The Kalilah Wa Dimnah is an exemplary work of animal-themed storytelling with moral values (Syalabi, 1970). Animal-themed stories translated into almost every language in the world have their own charm. According to Nurhasma, Kartina \& Rusni (2012), the use of animals as the main characters in delivering the key messages is more effective than conventional traditional stories. It is considered unique and more effective. This type of story also uses animals as symbols in literature. This is because some animals have characteristic traits which are already commonly known by the readers. Among them are the daringness of a lion, the slowness of a turtle and the cunningness of a fox. (Nurhasma, Kartina, Rosni, 2012) However, these characters differ from one culture to another. For example, the character of a donkey is a symbol of ignorance in the Arab community, but the Malay community instead use the cow as a symbol of the same nature.

Al-Zayyat (1999) mentioned that the usage of animal characters in the Kalilah Wa Dimnah book was a strategy to raise awareness and educate the leaders of the time. Despite the use of animal characters, the ideas and messages conveyed in this literary work represent the true reality of human life. The animal characters displayed highlight a number of specific symbols representing a wide range of attitudes such as courage, loyalty and wisdom (Nurhasma, Kartini, Rusni, 2012). These features make it easy for the reader to understand the underlying messages and to digest the moral values which are highlighted while reading. To date, the Kalilah Wa Dimnah book has been translated into Greek, French, Spanish, Italian, Dutch, German, and English (Mahadhir, 2008). According to Lunde, the Kalilah Wa Dimnah is also translated into ancient Greek, Latin, Old Church Slavic and German. The Arabic version was also translated into Syriac, Turkish, Malay, Japanese, Thai, and Ethiopian. In the 19th century, the Kalilah Wa Dimnah was translated into Hindi, completing a cycle that began 1,700 years ago in Kashmir (Lunde, 1972).

\section{Abdullah Ibn al-Muqaffa'}

Abdullah Ibn al-Muqaffa' (original Persian name: Ruzbeh bin Darzwaih) was of Persian origin and born in Barsah in 107H. He grew up as a Zoroastrian among the Arabs and was from the family of al-Ahtam who was famed for his fluency and knowledge. His Persian background as well as his background living among Arabs allowed him to master both the Persian language and the Arabic language. After the death of his father al-Muqaffa', he began his career in writing. During his 20s, he had served the then ruling Umayyad Habirah family. After the fall of the kingdom and the shift of power to the Abbasid caliphate, he began associating with the nobles such as the uncle of Caliph al-Mansur and worked as a scribe to Isa while he ruled the "Karman" region. At that time, he converted to Islam and was named Abdullah, and was given the "kunyah" (title) of Abu Muhammad. He was also appointed "muaddib" (teacher) to Bani Ismail who was then governor of "al-Ahwaz" at that time. (Kalilah wa Dimnah, n.d)

There was a very strong dispute among the founders of the Abbasid caliphate in the time of Ibn al-Muqaffa'. Abdullah bin Ali, the uncle of the Caliph al-Mansur, rebelled and turned his back on 
INTERNATIONAL JOURNAL OF ACADEMIC RESEARCH IN BUSINESS AND SOCIAL SCIENCES Vol. 10, No. 11, 2020, E-ISSN: 2222-6990 @ 2020 HRMARS

him, and al-Mansur sent an army led by Abu Muslim al-Khurasani for to launch a retaliatory strike. Abdullah bin Ali was eventually defeated and fled, seeking protection from his brother Sulaiman bin Ali, who was then the governor of Basrah. Sulaiman's action of defending of his brother angered the caliph al-Mansur. Therefore, Sulaiman was requested to resign, where he was removed from his position and replaced by Sufyan bin Muawiyah. The caliph then demanded that Sulaiman surrender Abdullah bin Ali to him, but he refused to do so except under certain conditions. At that time, Abdullah Ibn al-Muqaffa' was a scribe to Sulaiman and he was asked to write a treaty known as "alAman". With his wisdom, Abdullah Ibn al-Muqaffa' imposed strict conditions on suspicion of treason and deceit that led to al-Mansur's anger and grudge against him. In addition to caliph al-Mansur, Sufyan bin Muawiyah also held a grudge against Abdullah Ibn al-Muqaffa' for his insistence in giving his opinion and criticism to Sufyan. There are several versions of his death, including his being tortured by the Iraqi governor to death despite his powerful protector trying to save him (Jany Jonos, 2012). He died at the age of 36 . Though he died at a young age, he lived within two different eras of rule - the end of the Umayyad caliphate and the beginning of the Abbasid caliphate, hence earning him the title "Mukhadram." (living in two ages). (Kalilah wa Dimnah, n.d)

Abdullah Ibn al-Muqaffa' is considered by some scholars to be the smartest and most eloquent individual as well as being virtuous, generous and very loyal among regular people. This can be seen in an incident with his friend Abdul Hamid bin Yahya where he proved his friend's loyalty when he was willing to admit that he was Abdul Hamid himself when he was hunted down by the Abbasid authorities due to of Abdul Hamid's loyalty towards the previously fallen caliphate. (Kalilah wa Dimnah, n.d)

The turbulent political turmoil that affected the country during the reign of the al-Mansur caliphate at that time resembled that of King Dabsyalim's reign. This triggered the idea for Abdullah Ibn al-Muqaffa' to translate the book called Kalilah wa Dimnah. This book is considered to be the first Arabic literary work in the genre of moral values transmitted through animal tongues, as it is laden with advice and guidance. (Kalilah wa Dimnah, n.d)

\section{Imam al-Ghazali's Framework on Commendable Moral Values}

The establishment of superior morals requires individuals to strive and practice all these virtues as emphasized in the Quran and the Sunnah. With such efforts, individuals who are members of a community will be able to perform the religious duties and prevent harm. In turn, each individual in the community will play a role in forming a respectful and loving society that will ultimately form a harmonious society. In this regard, Imam al-Ghazali through the book of ihya 'Ulum al-Din combines the Ulum' Aqliyah (intellect) and the Ulum Diniyah (revelation-based knowledge) to form a complete Islamic philosophy to answer all questions related to matters of life. Although this book been authored by al-Ghazali a long time ago, a recent study by Sheikh and Ali (2019) indicated that some Islamic scholars assert that the guidelines regarding teaching and learning in the book are still relevant. Through the book, he presents four main principles that are fundamental to the formation of morals; al-Hikmah (Wisdom), al-Syaja'ah (Courage), al-'Iffah (Purity) and al-'Adlu (Justice) (AlGhazali, n.d). These elements are fundamental in shaping a noble personality as claimed in Islam. (Raihan \& Pabiyah, 2017) 
INTERNATIONAL JOURNAL OF ACADEMIC RESEARCH IN BUSINESS AND SOCIAL SCIENCES Vol. 10, No. 11, 2020, E-ISSN: 2222-6990 @ 2020 HRMARS

Al-Hikmah (Wisdom) is formed by the power of knowledge that drives an individual towards distinguishing between the right and the wrong in the world, between the truth and the falsehood in religious belief and between the noble and the vile in deeds (Al-Ghazali, n.d). From the power of knowledge comes the value of wisdom that is the main pillar of the construction of noble moral values. As a result, an individual's life will be under control in addition to being highly motivated in the pursuit of success and happiness (Al-Qasimi, 2006). Among the elements of Al-Hikmah listed by Imam Al-Ghazali are; the ability to manage situations well, to have a good mind or understanding, to be accurate in judgement, to have the right expectations and to be thorough and to refine any work one does (Al-Ghazali, n.d).

Al-Syaja'ah (Courage) is induced when the power of anger is subjugated, and instead controlled by intellect, which is only as necessary or shown by wisdom (Al-Ghazali, n.d.). According to Imam Al-Ghazali, Al-Syaja'ah embodies self-respect, bravery, power, speed and wisdom, striving to overcome lust and greed, assumptions and delusions, self-integrity, the ability to control anger, honor and compassion (Al-Ghazali, n.d.).

Al-'Iffah (Purity) is born from the power of syahwat that obeys wisdom (Al-Hikmah). Through Al-'Iffah, the individual will always maintain his own purity by protecting the self and avoiding wrongdoings and bad deeds (Al-Ghazali, n.d.). Al-'Iffah is characterized by one being generous, shy, patient, tolerant, accepting, religious, avoiding forbidden things, politeness, helpfulness and not succumbing to greed. (Al-Ghazali, n.d.).

The last element is Al-'Adlu (Justice) which is the power of the soul to control anger and lust and instead utilize justice to guide oneself according to their intellect and religion to attain Al-hikmah (Wisdom). Al-'Adlu (Justice) drives individuals toward safety, harmony, peace, and happiness. These four elements will create the exalted morals and enhance personal dignity, hence ensuring the wellbeing of the community. These values play a pivotal part in forming a peaceful and harmonious society.

Based on past studies of three important aspects, namely the study of Kalilah wa Dimnah, the author of the KWD Abdullah Ibn al-Muqaffa' and the study of Imam al-Ghazali's framework, it can be concluded that there are a number of studies that looked into on these three aspects, but all these studies carried out observations in different angles from the current study. Some studies discussed the originality of Kalilah wa Dimnah's itself as emphasized in Lunde's (1972)P: Al-Subayel (2007 and Roziah (2012) studies. Other studies have focused on the author of the book, Abdullah Ibu alMuqaffa' in terms of his background, his knowledge and his personality, which was highlighted in Janos's (2012) study. In addition, there have been studies that analyzed the use of animal characters in this literary work with the aim of determining their significance, which was carried out by Mahadhir (2008); Nurhasma (2012);Musa, Otunuyi, \& Ahmed (2012). Meanwhile, a recent study by Sheikh \& Ali (2019) looked into Imam al-Ghazali's ideas with the objective of determining the relevance of this ideas as a theoretical framework for analyzing data. Furthermore, studies were also carried out by Raihan \& Pabiyah (2017) using the text of Kalilah wa Dimnah as data and the idea of the Imam as the basis for determining moral values, but this study did not focus on the formation of a harmonious society. This study is, therefore, an extension of previous studies with an emphasis on the aspects of harmonious society formation. 
INTERNATIONAL JOURNAL OF ACADEMIC RESEARCH IN BUSINESS AND SOCIAL SCIENCES Vol. 10, No. 11, 2020, E-ISSN: 2222-6990 @ 2020 HRMARS

\section{Methodology}

This study is a qualitative in nature. Textual analysis is used as the main method to analyze the data of this study. Five stories out of a total of 16 stories were selected as the data of this study. The main source of data for this study is the Kalilah Wa Dimnah book containing 296 pages and is the first published version by Al-Maktabah Al Thaqafiyyah, Beirut, Lebanon. However, the year of publication of this book was not indicated in the source material. This book contains sixteen stories; five of them are original writings of Baidaba, while eleven others are additions made by Abdullah Ibn al-Muqaffa ' (Marroum, 2011).

The following table depicts five samples from the Kalilah Wa Dimnah which was used in the study:

Table 1 : Content Analysis Sample Units from Kalilah Wa Dimnah

\begin{tabular}{|c|c|c|c|}
\hline No. & Chapter & Page & Sample Title \\
\hline 1 & First & 109 & $\begin{array}{l}\text { باب الأسد والثور } \\
\text { (Lion and Cow chapter) }\end{array}$ \\
\hline 2 & Third & 172 & $\begin{array}{l}\text { باب الحمامة المطوقة } \\
\text { (Garlanded Pigeon chapter) }\end{array}$ \\
\hline 3 & Fourth & 190 & $\begin{array}{l}\text { باب البوم والغربان } \\
\text { (Owl and Two Crows chapter) }\end{array}$ \\
\hline 4 & Sixth & 222 & $\begin{array}{l}\text { باب الناسك وإبن عرس } \\
\text { (Devotee and Fox chapter) }\end{array}$ \\
\hline 5 & Seventh & 225 & $\begin{array}{l}\text { باب الجرذ والسنّور (Mouse and Wildcat chapter) } \\
\text { (Mouse }\end{array}$ \\
\hline
\end{tabular}

In order to analyze the data, Imam al-Ghazali's approach to moral value building will be applied. Each element will be matched with the characteristic traits of the characters in the selected stories from the Kalilah wa Dimnah. The four essential elements of moral development are; alHikmah (Wisdom), al-Syaja'ah (Courage), al-'Iffah (Purity) and al-'Adlu (Justice). These elements are fundamental in shaping a noble personality as emphasized in Islam.

\section{Analysis and Discussion}

Five stories will be analyzed based on the four elements of Imam al-Ghazali in the formation of morals, thus moulding a superior personality that is fundamental to the formation of a harmonious society. 
INTERNATIONAL JOURNAL OF ACADEMIC RESEARCH IN BUSINESS AND SOCIAL SCIENCES Vol. 10, No. 11, 2020, E-ISSN: 2222-6990 @ 2020 HRMARS

\section{Elements of al-Hikmah (Wisdom)}

Imam al-Ghazali has listed some attributes that are derived from al-Hikmah elements such as; the ability to manage things well, to have a good mind or understanding, to be well-informed, to have the right expectations, to be thorough and refine our work quality (Al-Ghazali, n.d.).

The ability to manage or the ability to organize and plan is a trait that leads to the achievement of a goal. This is because a goal will only be achieved through a sound approach and strategy. The wisdom of organizing and planning an action is a feature of Al-Hikmah that can only be obtained through the power of knowledge. This is explained by Imam al-Ghazali by saying (Al-Ghazali, n.d.); "If this strength is good (the power of knowledge), then it produces wisdom."(translation)

Through the book of Kalilah wa Dimnah in the al-Hamamah al-Mutawwqah chapter, the pigeon named Al-Mutawwaqah is portrayed as a wise leader in dealing with a troubling situation. Despite being caught in the snare, she is still able to take responsibility, advise and control her friends' emotions calmly and devise effective strategies to break free from the snare of hunters. It is this quality that makes Al-Mutawwaqah respected by all pigeons. In relation to this, Abdullah Ibn alMuqaffa' describes as the following:

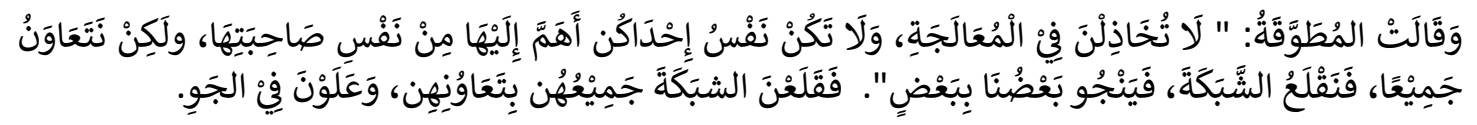

"And "Al-Mutawwaqah" said: "Do not abandon the solution (give up), no one is more important to you than a friend. (Come) let us help each other, we shall attempt to pull the snare (this trap), together we shall save ourselves." Hence, in cooperation with each other, they all managed to escape the snare and fly high in the skies". (pg 173)

Al-Mutawwaqah the pigeon was created by the author to demonstrate the importance of leadership. The story shows that a leader should have the wisdom to administer, control and plan his strategy. Such wisdom is vital in safeguarding the rights, safeguarding the interests and guaranteeing the well-being of the people under the leader. Implicitly, the author urges readers to strive to be responsible leaders, to work hard and to fulfill their obligations to ensure the well-being of the community. In this way, leaders will be respected, and the people will be loyal to leaders which will lead to the formation of a society that respects one another.

Wisdom is also capable of proving true and accurate thoughts or expectations. Through the story of Bab al Bum wa al-Ghirban (The Owl and the Two Crows chapter), the Crow King's advisers were able to determine that the power of the owl will be unmatched to the crows. According to adviser, the best way to deal with the strength of the owl is to avoid open warfare as shown in the following data:

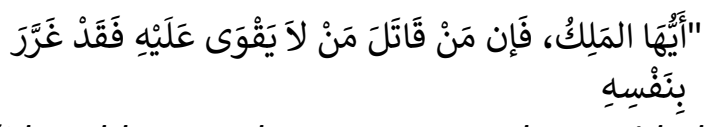

(The Crow King's advisor said): "O my Lord, (I humbly pray that a war must be avoided with the owls). Indeed, those who fight against an enemy while knowing they will not be able to defeat them, will instead deceive themselves". (pg194) 
INTERNATIONAL JOURNAL OF ACADEMIC RESEARCH IN BUSINESS AND SOCIAL SCIENCES Vol. 10, No. 11, 2020, E-ISSN: 2222-6990 @ 2020 HRMARS

By being wise in setting strategies as well as the right thoughts or expectations, a leader in particular can create a community capable of dealing with all obstacles as shown by the pigeon named al-Mutawwaqah. Even the right thinking or expectations are also very important in a community even if the decision made in its own right reflects the weakness of the community. But in order to save the community from greater danger, a wise action must be taken first.

\section{Elements of al Syaja'ah (Courage)}

When the power of anger is subjugated by intellect and Islamic law, it is transformed into Al-Syaja'ah (Courage) (Al-Ghazali, n.d.). The analysis carried out in the current study revealed that several elements of Al-Syaja'ah shaped the theme of the story and contained moral values for the readers' knowledge and benefit. The elements of Al-Syaja'ah include themes such as the courage to defeat the enemy, the love of one another, abstaining from self-praise, pride and arrogance, avoiding emotions and anger, and avoiding acts of aggression without any investigation of the matter at hand.

Al-Syaja'ah is embodied in the bravery of a fox who seeks to defeat his enemy solely in defense of his master's son. The data from the chapter of the Devotee and the Fox below illustrate the sincere actions of the fox when it attempted to sacrifice its life to protect its master from being attacked by a black snake. This situation is illustrated by the author as follows:

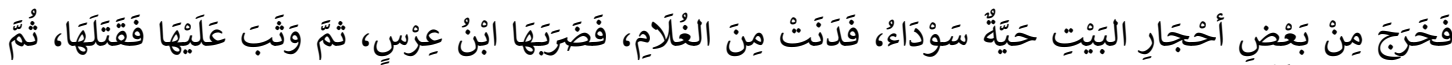

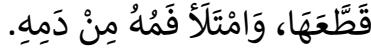

Then a black snake appeared in the cracks of his house, approaching his son. Immediately he (fox) fought against him, then pounced on him and killed him. Then the fox bites it until its mouth is covered with the blood of the snake. (pg 224)

In addition to that, al-Syaja'ah will also shape individuals to become humble, not proud and arrogant. On the contrary, if the individual does not practice humility, then their pride and arrogance will overcome them. Such an instance is described by the author through the character of the lion. The uncontrolled anger of the lion king gave way to pride and arrogance to the point where the lion was able to disparage Syatrabah. He did not think he could be defeated by Syatrabah, a herbivore as described by Abdullah Ibn al-Muqaffa';

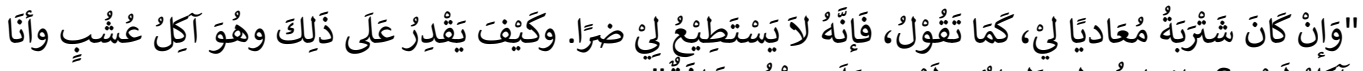

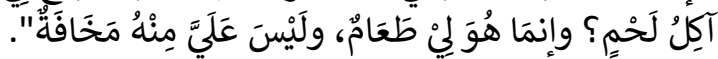

"Even if Syatrabah makes an enemy of me as you say, he cannot harm me. How could he do that; he's a grass-fed animal while I'm a meat-eater? He is merely a source of food to me, and I have no reason to fear him". (pg 132)

According to Al-Ghazali, excessive and unreasonable anger facilitate an individual to utter profanities, curse, ridicule and insult others (Al-Ghazali, n.d.). Based on this description, the author urges the reader not to be arrogant, insult or criticize other individuals. Instead, they should practice humility and modesty. By adopting these traits, they will become loving and harmonious individuals within their societies. 
INTERNATIONAL JOURNAL OF ACADEMIC RESEARCH IN BUSINESS AND SOCIAL SCIENCES Vol. 10, No. 11, 2020, E-ISSN: 2222-6990 @ 2020 HRMARS

True courage enables an individual to do something unexpected, even in the face of personal danger. In fact, true courage also makes the individual humbler. This may seem strange to some individuals as society often assumes that the nature of courage is synonymous with pride and arrogance. Whereas humility is often associated with weakness and cowardice. This is in line with the Hadith of the Rasulullah (SAW) narrated by Imam Ibn Mandah and Imam Abu Nu'aim from his friend Aus bin Khauli that the Prophet said,

$$
\text { قَالَ النَّبِيٌُ صَلَّى اللهُ عَلَيْهِ وَسَلَّمَ: }
$$

Which means: "Whoever subjugate themselves to Allah, then Allah will raise their (place) (in this world and the hereafter), and whoever is arrogant then Allah will lower their place."

Elements of al-'Iffah (Purity)

Al-'Iffah (purity) is to educate the strength of lust with the guidance of intellect and religion in order to constantly protect and refrain oneself from evil and bad deeds (Al-Ghazali, n.d.). The analysis found that the form of Al-'Iffah (purity) which the author sought to highlight was based on several themes such as helping each other and cooperating, avoiding greed and excess, discouraging and avoiding vanity and malice and as well as refraining from al-Syamaatah (happiness caused by the misfortune of an opponent).

The helpful and cooperative nature of the characters is displayed through the Mouse and the Wildcat chapter. The hostile characters Faridun and Rumi at first turn to each other when in need. This situation proves that the power of lust that is subjugated by the intellect can turn into 'Iffah; the feelings of hatred between Faridun and Rumi can turn into mutual respect and cooperation. This is what happens when they realize they need each other because they have to deal with other enemies that are more difficult to overcome as the authors describe in the following excerpts:

$$
\text { " فَاِنْ جَعَلْتَ لِيْ الأَمَانَ قَطَعْتُ حَبَائلَكَك، وَخَلصْتُكَكَ مِنْ هَذِهِه الوَرْطَةِ" }
$$

(Faridun said): "If you save me, I will sever the trap (in which you are trapped), and I will release you from this suffering.". (pg 228)

Uncontrolled lust leads to a desire for position and rank. In order to obtain it, humans are willing to do anything, even though they have strayed from the right path. This is reflected in the character of Dimnah who wishes to stand out without any competition from Syatrabah. The following data excerpt illustrates the envy and hatred within Dimnah after learning of Syatrabah's advantage;

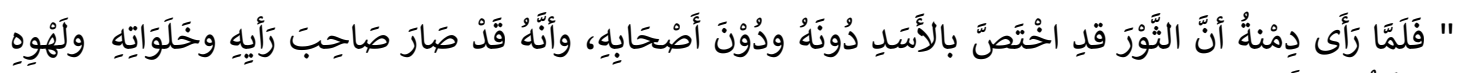
حَسَدَهُ حَسَدًا عَظِيْما".

"When Dimnah saw that the bull had become a priority for the King of the lions instead of himself and his companions, and to be his advisor and close companion (in love and sorrow), he developed a strong sense of envy.". (pg 122) 
INTERNATIONAL JOURNAL OF ACADEMIC RESEARCH IN BUSINESS AND SOCIAL SCIENCES Vol. 10, No. 11, 2020, E-ISSN: 2222-6990 @ 2020 HRMARS

Based on the analysis above, the author stresses that every individual in the community should be courageous and guided by reason and religious teachings. On the other hand, if this attitude is not guided by reason and religion, then there will be arrogant individuals akin to the lion character as well as individuals with envy. By controlling lust, striving, exercising a healthy mind, malice and envy will vanish and turn to love and acceptance in full accord with all His requirements. (Al-Qasimi, 2006)

The element of purity guided by the intellect and the guidance of religion will produce individuals who cooperate in the pursuit of a desired goal. This is even observed in certain circumstances which require an individual to co-operate with someone who was once considered an enemy. On the other hand, if this element is ignored, it will give rise to individuals who are jealous and dissatisfied with others. This will not contribute to the formation of a harmonious society. This is because every individual in the community is an important component in building a community.

Elements of al-'Adlu (Justice)

Al-'Adlu (Justice) is the power of an individual to control their anger and lust that is maintained and guided by intellect and religious teachings in order to appropriately achieve Al-Hikmah (Al-Ghazali, n.d.). This power will motivate individuals toward attaining safety, harmony, peace, and happiness. An analysis of the elements of 'Adlu (Justice) in the story finds several themes such as not being biased or unjust, taking things into consideration with fairness as well as putting things it the right place.

A selfless or unbiased attitude is reflected in the conversation between Dimnah and the lion king. The king of lions attempted to be fair towards the alleged accusation on Syatrabah. In this situation, the lion king tried to justify his desire to avoid hostility with Syatrabah. He did not only describe Syatrabah as an individual who always appealed to the good, but also denied the legitimacy of Syatrabah's to deceive and destroy him.

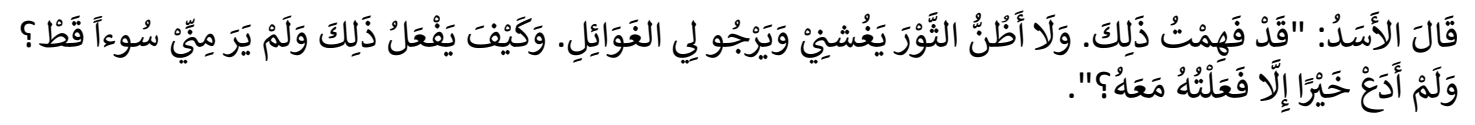

The lion said: "I understand (your explanation). (However), I do not believe that the bull (Syatrabah) deceived me and wanted to destroy me. How could he do that when he never saw me commit a crime? And I never asked for a deed unless he did it with me?".

(pg 131)

In another situation, the pigeon Al-Mutawwaqah is portrayed as a character who has always maintained a friendly relationship among his companions. The deepest love and passion in AlMutawwaqah subjugated her self-righteousness according to her will and intellect. This has led to the generosity of being willing to put others ahead of herself. Al-Mutawwaqah does not worry about her own condition still trapped in the trap, but instead prioritized the safety of her friends. Thus, AlMutawwaqah ordered Zairaka to release her companions first by severing the snare that held them captive before releasing her. 
INTERNATIONAL JOURNAL OF ACADEMIC RESEARCH IN BUSINESS AND SOCIAL SCIENCES Vol. 10, No. 11, 2020, E-ISSN: 2222-6990 @ 2020 HRMARS

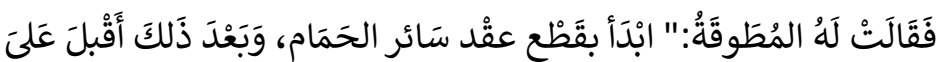

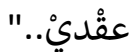

Al-Mutawwaqah said to him (Zairaka): "Begin by cutting off the snare (of my) fellow pigeons, and then you may cut the snare on me.". (pg 175)

The trait of giving importance toward others before oneself is of the highest level of generosity and is the attribute of Rasulullah (SAW) for which he is praised by the title of Al-'Azim (of great virtue) (Al-Qasimi, 2006). In terms of linguistic definition Al'adlu also means giving individuals their rights as well as taking away their rights (al-Mu'jam al-Wasit, 2004). In other words, al-'adlu is to put something in its place. Therefore, individuals of this nature will act fairly and will not be biased in any way, even to their own family members. Al-'adlu will also produce individuals who are unselfish and capable of putting others first. This was proven by Abdullah Ibn al-Muqaffa' when Abdul Hamid, his comrade, was being hunted down by government troops, and at that time he claimed to be Abdul Hamid.

Based on the above data, the author wishes to emphasize the value of optimism and to speak in good words to maintain the harmony of one another's life which will lead to a peaceful and harmonious life in society.

\section{Conclusion}

Any literary works should contain moral values and beneficial messages that contribute to the formation of a noble personality and a harmonious society. Based on the analyses of the five stories in Kalilah wa Dimnah, Abdullah Ibn al-Muqaffa ' sought to cultivate positives virtues to be taken as examples by society with the aid of emulating various animal characters in his literary works. In addition, he also sought to expose the appalling nature of bad virtues which is meant to be abstained by drawing a line between good and bad virtues, especially between leaders and the people. Through this medium of storytelling, this work is able to educate the public, especially governing bodies, about the misdeeds that happen in daily life. In addition, the author also suggests the strengthening of the bonds of friendship to remain intact through the practice of moral values. In addition to moral values, especially those related to leadership and friendship values, various aspects or angles can be explored through Kalilah wa Dimnah both in terms of its storytelling as well as the message intended to be conveyed by the author. This is because the book is rich in aesthetics and ethical values to serve as an example in educating the public. From a storytelling point of view, important elements such as the theme, characters, plot, timeline and place and messages, can be analysed in depth to discover the author's creativity in presenting all these elements. Meanwhile, from an ethical point of view, apart from the two important points, namely the values of leadership and the values of friendship discussed in this article, the researcher could, for instance, highlight the element of humor in conveying the important messages in this book.

Based on Imam al-Ghazali's approach, which presents four main principles that are elements in the formation of morality, namely wisdom, courage, purity and justice, we have identified two other important elements that a leader must have in addition to the four elements outlined by him. The two elements in question are the value of respecting the views of others and the value of politeness in speaking. Both of these values are also important to be possessed by a leader who is 
INTERNATIONAL JOURNAL OF ACADEMIC RESEARCH IN BUSINESS AND SOCIAL SCIENCES Vol. 10, No. 11, 2020, E-ISSN: 2222-6990 @ 2020 HRMARS

seen to be able to strengthen the relationship between leaders and society as shown by Abdullah Ibn al-Muqaffa' through the chapter "Ows and Crows". The findings of the study also show that Kalilah wa Dimnah remains relevant to the current context in cultivating the noble values that leaders need in order to create a harmonious society, especially in the context of the current situation which requires a leader who is responsible and concerned for the welfare of the people and not selfish. This is despite the fact that the book was written hundred years ago using animal characters. This proves that literary works, such as Kalilah wa Dimnah can serve as a guide in moulding a leader towards spearheading over a harmonious and prosperous society.

\section{References}

Al-Fakhuri, H. (1991). Al-Mujiz fi al-Adab al-Arabi wa Tarikhihi. (Vol.2). Beirut: Dar al-Jil.

Al-Ghazali, A. H. M. (n.d.). Ihya Ulum al Din.(Vol. 3). Beirut: Dar al-Kutub al-Ilmiah.

Al-Muqaffa', A. I. (n.d.). Kitab Kalilah Wa Dimnah. Beirut: Al-Maktabah Al-Thaqafiyyah.

Al-Qasimi, M. J. (2006). Mau'izah Al-Mukminin Min Ihya' Ulum Al-Din: Intipati Ihya' Ulumuddin: Pengajaran Bagi Orang-Orang Mukmin. (Abu Hasan Din Al-Hafiz, Ed.) (1st ed.). Kuala Lumpur: Dar al-Fajr.

Al-Rafei, M. (1968). Hadarah al-Arab fi al-usur al-islamiyyah al-zahirah. (2nd ed.) Beirut: Dar al-kitab al-lubnani.

Al-Subayel, W. I. (2007). Animal Fables between "Panchatantra (Kalila wa Dimna)' and "Tales of Aesop "-A Literary Study. (Doctoral Dissertation). Al-Imam Muhammad Ibnu Saud Islamic University.

Al-Thubaity, N. (2006). Tanawwu' Al-Ada'i Al-Balaghi Fi Adabi Ibnu Al-Muqaffa'. (MA thesis). University of Ummu Al-Qura.

Al-Zayyat, A. H. (1999). Tarikh al-Adab al-Arabi. (5th ed.). Beirut: Darul Ma'rifah.

Omar, A. (2015). Pendidikan Sastera Remaja Di Malaysia Dalam Membina Generasi Unggul Berasaskan Falsafah Pendidikan Negara. Jurnal Pendeta Vol. 5, 1-22.

Bertens, K. (2002). Etika. Jakarta: Gramedia Pustaka Utama.

Hancock, Z. D. (2004). The Spanish Shahrazd And Her Entourage: The Powers Of Storytelling Women In Libro De Los Engaños De Las Mujeres. (Doctoral Dissertation). University of Maryland.

Iwadh, A. (1982). Dirasah Tahliliyyah Li al-Qiami al-Saidah Fi Qisasi al-Athfal al- Mansyurah Min Qibali Kuttab Urduniyyin Fi al-Muddah Ma Baina 1950-1980. (MA Thesis). The University of Jordan.

Janos, J. (2012). The Origins of the Kalilah wa Dimnah: Reconsideration in the Light of Sasanian Legal History. Journal of Research in Ayurvedic Sciences. Vol.3, pp 505-518.

Kamus Dewan Edisi Keempat. (2005). Kuala Lumpur: Dewan Bahasa dan Pustaka.

Hasan, L. (1984). Masadir al-Hikmah fi Qisas Kalilah wa Dimnah. Amman: Dar al-Fikr li al-Nasyr wa alTauzi'.

Lunde, P. (1972). Kalila Wa Dimna. Jurnal Saudi Aramco World, 23(4), 18-21.

Radzi, M. (2008). Kalilah wa Dimnah Dari Sudut Pandangan Teori Persuratan Baru. Retrieved from http://my/201505/kalilah-wa-dimnah-dari-sudut-pandangan.html..

Marroum, M. (2011). Kalila wa Dimna Inception, Appropriation and transmimesis. Comparative Literature Studies. 48 (4), 512-540.

Musa, I. A., Otunuyi, A. K. T., \& Ahmad, A. F. (2012). Introducting Arabic Stories. Lagos: National Open University of Nigeria.

Khalid, O. (1989). Kesusasteraan Arab di zaman Abbasiah, Andalus dan zaman Moden 
INTERNATIONAL JOURNAL OF ACADEMIC RESEARCH IN BUSINESS AND SOCIAL SCIENCES

Vol. 10, No. 11, 2020, E-ISSN: 2222-6990 @ 2020 HRMARS

. Johor: Darul Nadwah Muadzam Shah.

Marzuki, R., \& Toklubok, P. (2107). Elemen pembinaan akhlak al-Imam al-Ghazali menerusi karya klasik Kalilah wa Dimnah. Malaysian Journal for Islamic Studies. 1 (1) 25-44.

Sidik, R. (2012). Relevansi Faktor Kegemilangan Sains Islam Dengan Dunia Islam Masa Kini. Jurnal Al-Tamaddun, 7 (1), 1-13.

Shalabi, A. (1970). Al-Tarikh al-Islami Wa al-Hadharah al-Islamiyyah. (Vol.3). Qaherah: Maktabah alNahdhah al-Misriyyah Qaherah.

Sheikh, S. U., \& Ali, M. A. (2019). Al-Ghazali's aims and objectives of Islamic education. Journal of Education and Educational Developement, 6 (1), 111-125.

\section{Authors' biodata}

\section{Corresponding Author}

Pabiyah Toklubok is a Senior Lecturer at the Department of Foreign Languages, Faculty of Modern Languages and Communication, Universiti Putra Malaysia, Serdang. She obtained her PhD in Literature from the International Islamic University Malaysia, IIUM. Her area of specialisation is Comparative Literature: Arabic -Malay, and her research interests are Malay and Arabic literary works focusing on comparative elements.

Tel no: +60193970995

Email: pabiyah@upm.edu.my

\section{Co-authors}

Kamariah Kamarudin is an Associate Professor at the Department of the Malay Language, Faculty of Modern Languages and Communication, Universiti Putra Malaysia, Serdang. Her area of expertise is Modern Malay Literature specifically on novels while her research interests are Malay literary works and Islamic Literature. She has won various literary awards at national levels such as the National Academic Award in 2019.

Tel no: +60122121882, email: kkamaria@upm.edu.my

Zaitul Azma Zainon Hamzah is an Associate Professor at the Department of the Malay Language, Faculty of Modern Languages and Communication, Universiti Putra Malaysia, Serdang. She currently holds the position as Head of the Malay Language department. Her area of specialisation is Semantics and Pragmatics, and she has published works in her area focusing on politeness in language.

Tel no: +6012 2729088, email: zazh@upm.edu.my

Raihan Marzuki is a language instructor at the Centre for Languages and Cultural Diplomacy, Institute of Diplomacy and Foreign Relations (IDFR), Ministry of Foreign Affairs, Malaysia. She obtained her PhD in Arabic Language from Universiti Putra Malaysia, Serdang. Her research interests are in Arabic Language and Literature, Applied Linguistics and Teaching Arabic as a Foreign Language. Tel no: +601127164298, email: raihanmarzuki@yahoo.com 